\title{
INTERFACE
}

Sociologias, Porto Alegre, ano 11, no 21, jan./jun. 2009, p. 318-343

\section{Significados de violência em abordagens da mensagem televisiva ${ }^{1}$}

NAPAMAGAHÃE*

\section{Resumo}

Este artigo aborda a multiplicidade de significados da violência apontada pelos estudiosos, comparando-a com estudos empíricos realizados em uma cidade de médio porte do interior do Estado do Rio Grande do Sul, Brasil. A seguir, discute a ausência dessas várias significações, tanto no espetáculo televisivo, quanto na percepção das pessoas pesquisadas, e a presença de estereótipos na construção de mensagens da televisão e em suas interpretações. Busca, também, expor outros dados para explicar a percepção das pessoas pesquisadas sobre 0 aumento da violência no contexto local. Problematiza, por fim, a cultura do medo, sugerindo que ela pode ser alimentada não só pelo alarme das pessoas pesquisadas que assistem ao espetáculo televisivo, mas também pelo próprio modo de alguns estudiosos analisarem este mesmo espetáculo. A reflexão busca demonstrar que existem concepções reificadas de violência, imagem e realidade, presentes no debate, que retro alimentam a percepção de aumento da violência e o sentimento de insegurança daí decorrentes.

Palavras-chave: Violências. Estudos de recepção. Espetáculo televisivo. Cultura do medo. Antropologia da mídia.

* Pesquisadora Pós Doutoranda Associada ao Núcleo de Antropologia e Cidadania (NACI), PPGAS/UFRGS.

1 U ma outra versão deste texto foi apresentada em palestra proferida aos alunos do Curso de

Ciências Sociais da Universidade Federal de Santa Maria, em agosto de 2006. 
As reflexões que desenvolvo aqui são construídas com base em uma experiência de pesquisa sobre o significado da televisão, realizada com pessoas de camadas médias de uma cidade do interior do Rio Grande do Sul, Brasil. Abordo o tema ressaltando os vários significados da violência, do ponto de vista de estudiosos do assunto, cotejados à abordagem da televisão, a partir desse viés de pesquisa, com a intenção de refletir sobre as conseqüências desse debate para quem deseja elaborar políticas públicas.

\section{Violência ou violências?}

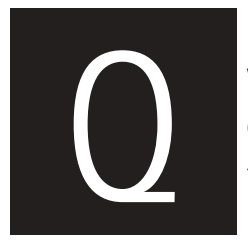

uando estudamos os fenômenos que são chamados de violência, percebemos que há um conjunto de práticas diferentes, reunidas sob a mesma denominação. Fica oculto um processo social de homogeneização e ressignificação, isto é, a passagem de um significado positivo a um significado predominantemente negativo, que é apresentado como exclusivo.

U m dos autores que pode ajudar-nos a entender essa multiplicidade dos significados da violência é Mafesoli. Em La violence ou le desir du collectif, o autor começa afirmando que a violência nada mais é do que a recusa da atomização, a busca da união: la violence n'ést en fait q'une expression paroxystique du désir de communion (M AFESO LI, 1979, p. 171). 0 autor ressalta que a figura do inimigo é um constituinte importante, até fundamental, do fato social ${ }^{2}$. Ele cita como exemplo o mundo grego, onde as guerras eram constantes. N esse contexto, uma festa interrompia as hostilidades e a destruição: os jogos olímpicos. A festa, além do caráter sagrado, teria como função reconstituir uma comunidade. Representaria uma

20 utros autores, como Girard (1990) e Rifiotis (1998), concordam com esta afirmação, destacando o papel do inimigo comum que é o "bode expiatório". 
eufemização do sacrifício. Na violência, o paroxismo e o excesso representam a negação sacrificial de tudo o que nega a vida. Por outro lado, de maneira homeopática e ordenada, uma violência dominada permite recriar aquilo que uma violência desenfreada havia exacerbado. Na visão do autor, a violência joga plenamente seu papel de fundação ou de regeneração da comunidade. Seria uma prova de que o irracional faz parte também desta obra humana que é a sociedade. A perversidade seria um resíduo da ação social principal - a tentativa de fundar a comunidade - presente em todas as sociedades (MAFESO LI, 1979).

Vista assim, a violência pode ser marca para falar das diferenças: ela garante dispersão, mas também unidades locais. É uma característica das sociedades contemporâneas a complexidade, a fragmentação, a construção de unidade nas diferenças. Este é um movimento contrário à homogeneização, mas que garante coesão. Há uma comunhão com tensões, com diferenças e não, uma homogeneidade. Com essa abordagem, podemos refletir sobre a sociabilidade como um processo que não é nem tão perfeito, nem tão sem falhas de comunicação como imaginamos.

Também Giddens, em seu conhecido livro A Transformação da Intimidade, afirma que:

a força e a violência fazem parte de todos os tipos de dominação. No domínio ortodoxo da política, surge a questão de até que ponto o poder é hegemônico, de tal forma que só se recorre à violência quando a ordem legítima entra em colapso, ou alternativamente, até que ponto a violência expressa a verdadeira natureza do poder do Estado (GIDDENS, 1993, p. 136).

N esta visão, o poder e violência aparecem muito imbricados, e os aspectos negativos ficam descartados: justifica-se e é considerada legítima, e muitas vezes sequer é assim nomeada, a violência exercida 
pelo Estado ${ }^{4}$. Também na obra já citada de Mafesoli (1979) encontramos este aspecto da violência coletiva. 0 autor considera que a sociedade se constrói sobre diferenças e contradições e não, sobre homogeneidade. Para ele, em nome do coletivo, muitas perversidades são praticadas. Q uando tornado coletivo, qualquer ato violento é aceito sem ser assim considerado: guerras e combates, repressões, rituais, suicídio. Quando autorizada pelo coletivo, até a morte - que é considerada a forma de violência mais extrema - é admitida.

O coletivo, para M afesoli, é fundado, portanto, não no consenso, na harmonia, ou no entendimento, mas no conflito ${ }^{5}$, no confronto, na comunicação entendida de modo amplo (incluindo o que não é dito). Entende-se por que a violência, como uma linguagem que comunica algo, joga um papel fundante da comunidade: revela o desejo de união. Com isso, aparece um surpreendente (em nosso contexto) significado positivo para o fenômeno.

No campo de pesquisas sobre o tema, ressaltar os múltiplos significados da violência e ir além dos estudos sobre as causas, tem-se revelado uma nova tendência, que pode auxiliar na busca de soluções para os problemas sociais reunidos sob o mesmo rótulo ${ }^{6}$. Para Rifiotis, por exemplo, a violência é um objeto reificado, que não existia como tal até os anos 70, período em que apareceu já sob o signo da violência urbana. 0 autor nos lembra que violência é um termo do latim vis, que significa força. No século XIII, violência, que significava força, virou abuso da força; no século XX ganhou novo significado: força brutal para sub-

3 As perspectivas contemporâneas sobre a violência do coletivo remetem à clássica abordagem de Weber sobre o monopólio da violência legítima por parte do Estado. Ver, a respeito, Weber (1971 e 1986).

4 A presença do conflito no processo de sociabilidade já está presente em Simmel (1992).

6 É o caso dos estudos de Tavares dos Santos (1999), O sório (1999) e também Rifiotis (1999). 
meter alguém. Para ele, "houve uma ampliação do campo semântico da violência nos últimos anos, mas o que está aumentando é o significado negativo" (RIFIOTIS, 1999, p. 28).

Ao mesmo tempo em que aumentou o processo de denominação de diferentes práticas sob o mesmo rótulo, aumentou o sentimento de insegurança, porém, muitas vezes, os índices que tentam medir o fenômeno não mostram igual crescimento. Foi o que demonstrou um estudo de Luiz Eduardo Soares, que chamou de cultura do medo a homogeneização realizada quando se associam diferentes práticas sociais à violência (SO ARES, 1996). Rifiotis (1996, p.2) apresenta objeções a essa expressão, por considerá-la muito ampla para dar conta da especificidade do nosso objeto. M esmo sem concordar com a designação de cultura do medo, Rifiotis - como outros autores - está preocupado em "entender essa polissemia que cerca o campo da violência, e osusos e abusos do termo, que acabam impedindo uma compreensão mais clara do fenômeno" (RIFIOTIS, 1997, p. 12 e 13).

O utra questão importante para a abordagem da violência é analisar o imaginário que associa criminalidade e pobreza. U m estudo de Alba Zaluar, por exemplo, mostra uma situação grave nas favelas do Rio de Janeiro. À medida que o tráfico de drogas tornou-se um negócio (uma das primeiras empresas capitalistas globalizadas - ilegal, mas lucrativa), cada vez mais, são os jovens favelados os grandes prejudicados, pois a sociedade não Ihes oferece alternativa: se eles não forem para o mundo do crime, de qualquer modo a sociedade os considerará criminosos. Suas afirmações nos instigam a pensar numa lógica perversa: o que eles teriam a perder, uma vez que já são considerados "bandidos" por uma sociedade que os rotula, mesmo "antes" de o serem ou nunca pretendendo sê-lo? Além disso, os "salários" oferecidos pelos traficantes locais são tentadores, muitas vezes mais do que seus pais ganhariam em um ano. As quadrilhas acabam realizando uma espécie de "socialização às avessas" desses jo- 
vens, que morrerão no máximo aos 25 anos, segundo a crua estatística sobre a expectativa de vida de jovens envolvidos no tráfico (ZALUAR, 1985).

Por outro lado, "não se tem conhecimento de que o salário ou a renda familiar das famílias pobres no RJ tenha aumentado após a quantidade de roubos, seqüestros, assaltos ou aumento do consumo de drogas ilegais [... a taxa de famílias abaixo da linha de pobreza aumentou [...]" (ZALUAR, 1999, p. 96).

O u seja, não são os pobres que estão enriquecendo com o tráfico, e as vultosas quantias ganhas neste negócio não estão na favela. Mas a polícia e a justiça brasileira continuam a optar preferencialmente pelos pobres na busca da responsabilização (ZALU AR, 1999). A autora ressalta que continuar tratando genericamente da violência como resultado da pobreza, sem reconhecer a globalização do crime, levará à continuidade do traçado de políticas públicas equivocadas, com conseqüências desastrosas para as comunidades envolvidas.

O utro estudioso do fenômeno, Sérgio Adorno, em seu artigo "Violência, ficção e realidade", demonstra que a "mídia faz uma leitura parcial dos chamados índices de violência, de forma a apresentá-los sempre como em expansão". No entanto, continua o pesquisador, "se fôssemos comparar os índices de criminalidade com os índices de crescimento populacional, ao invés de crescimento da violência, teríamos até mesmo uma taxa negativa" (AD O RN O, 1995, p. 186-187). Apesar disso, "continua existindo na população uma percepção ${ }^{7}$ de aumento da criminalidade e, em especial, da criminalidade violenta" (id., p. 183).

Também para esse autor, a percepção da violência é diferente da concretização da mesma: a percepção seria mais forte que a informação objetiva e não dominada pela racionalidade. Ainda que a racionalidade

7 Note-se que o autor usa a categoria de percepção para referir-se não só às representações da população sobre violência, mas também às sensações relacionadas ao fenômeno, aos sentimentos de medo e alarme, que extrapolam a racionalidade. U so percepção no mesmo sentido. 
possa modificar a percepção, no caso dos fenômenos agrupados sob 0 nome violência isto parece não acontecer.

\section{0 contexto local}

O s estudiosos da violência têm ressaltado a pluralidade de sentidos e a homogeneidade com que o termo é empregado em nossas sociedades contemporâneas, com a predominância de um sentido negativo. Têm destacado o tratamento do fenômeno como espetáculo midiático, têm mostrado que a complexidade da busca de soluções está além da procura das causas (que pode contraditoriamente, realimentar o processo) e têm mostrado também as rotulações e estereótipos que fazem recair uma culpabilização sobre os pobres.

$\mathrm{N}$ a pesquisa realizada sobre televisã $0^{8}$, também encontramos dados que demonstram empiricamente a complexidade deste processo. No entanto, através da análise dos depoimentos e observações, percebe-se que os meios de comunicação de massa, mesmo sendo um dos agentes da negatividade sobre a violência, não são os únicos, pois esta negatividade está inserida num processo de significação mais amplo.

0 relato de um episódio parece exemplar a respeito do sentimento de violência ou de risco que as pessoas vivem na sociedade de hoje: era o período de início da referida pesquisa, durante o qual eu e três alunos realizávamos entrevistas, contando com o auxílio de um roteiro aberto de questões - para identificar se a TV fazia parte do lazer, se era buscada como fonte de informação, quais as principais críticas e o que era considerado positivo em sua mensagem. Propositadamente, a metodologia previa

8 Refiro-me a uma pesquisa realizada de modo intermitente, entre os anos de 1997 e 2004, e que resultou em minha tese de doutorado, a qual contou com várias técnicas de coleta de dados: inicialmente entrevistas com roteiro de questões, depois etnografia de audiência, coleta de novos depoimentos, gravação de imagens para vídeos, fotos e observações, realizadas em locais de residência e públicos, no cotidiano e em festas locais. Ver Magalhães (2004). 
que nesse momento ainda não haveria um tema recortado para trabalhar no vasto mundo da comunicação televisiva. $M$ as ele foi aparecendo forte já nas primeiras entrevistas: a violência?

U m daqueles fatos que acontecem nas margens do processo de pesquisa e que, em geral, são contados como folclores do campo em corredores, aquilo que Da Matta chamou de antropological blues, aconteceu nesse momento.

Durante a realização de uma entrevista, toca o telefone na casa de uma entrevistada, e ela se mostra agitada. Vai até a janela e volta, confirmando: "É, eu vi, tem um homem lá fora! Q uem será? Por que está ali parado?... O quê?... Está ali há mais de uma hora?... Não sei se é o caso de chamar a polícia..." As exclamações, o olhar pela janela, a fala alarmada, 0 medo, finalmente chamam a atenção da entrevistadora, que esclarece e tranqüiliza a dona da casa: quem está lá fora é seu conhecido, al guém que a espera no carro!

O episódio mostrou um drama atual: também numa cidade de médio porte do interior do Rio Grande do Sul não se pode transitar livremente, ou escolher parar o carro em uma rua qualquer. Também ali há uma mudança de significado do uso do espaço público. Parar ou deslocar-se em uma rua à noite pode despertar suspeita e, em nome do medo da violência, é preciso explicar uma simples presença naquele espaço, antes considerado de livre circulação e uso.

Naquele longo minuto de pânico que envolveu o medo de um desconhecido parado perto de sua casa à noite, várias idéias podem ter sido cogitadas pela entrevistada e sua vizinha. Porém, mais do que a vivência da violência, parecia que o que as assustava estava muito informado pela

90 surgimento do tema violência no início da pesquisa sobre televisão gerou um novo projeto para investigar o assunto, intitulado: "Representações de violência a partir da recepção da mensagem televisiva: vivência ou simulacro?", que foi executado com auxílio de Bolsistas de Iniciação Científica do CNPq. 
televisão, pois o contexto local não permitia afirmar a recorrência de episódios violentos (ainda que a percepção fosse outra).

A semelhança com os estudos realizados por Tereza Caldeira era instigante. Analisando as novas maneiras de morar de grupos de camadas médias e altas, nos chamados enclaves fortificados em grandes cidades como São Paulo e Los Angeles, esta autora detecta tendências que solapam os ideais modernos de separação público-privado e aponta alguns comportamentos desses grupos que, em nome da segurança e do medo da violência, adotam medidas de controle e cerceamento do direito de livre circulação no espaço público, de indivíduos considerados suspeitos (CALDEIRA, 1997).

Buscar entender como, numa cidade de médio porte do interior, os entrevistados revelam temores e preocupações com a violência e ideais de moradia muito semelhantes ao de moradores de grandes metrópoles mundiais, tornou-se, então, um dos caminhos frutíferos de análise. E a relação mais evidente parecia ser a abordagem da violência pelos meios de comunicação de massa. 0 assunto estava sempre na pauta dos telejornais, que eram justamente os programas que apareciam como prediletos nas entrevistas. A partir daí, realizamos uma série de pesquisas, enquetes, observações na cidade, para buscar entender esse sentimento de violência, para verificar se ele correspondia a uma vivência ou se era um imaginário resultante da interpretação realizada sobre a abordagem televisiva.

O episódio foi bastante revelador sobre a modificação do espaço público e reforçou também uma afirmação de M artín-Barbero (1997): se a televisão atrai, isso é, em boa parte, porque a rua expulsa. É a ausência de espaços para comunicação - ruas e praças - que faz com que a televisão seja algo mais que um instrumento de ócio, um lugar de encontro. No caso da cidade analisada, não há uma ausência de espaços públicos fisicamente considerados, mas há uma ausência simbólica: as pessoas não os 
consideram locais adequados para o lazer e a comunicação, pelo menos não à noite. No cotidiano, a única praça local é um lugar de passagem; aos domingos ou fins de semana é utilizada pelos jovens adolescentes para ouvir música em volume acima da média em seus carros. Um costume interessante do uso do espaço público ali é aquele já conhecido de quem está familiarizado com o modo de vida no Interior: passear de carro, seguindo por uma avenida principal e contornando a praça. Mas é uma prática predominantemente diurna, pois o objetivo é ver e ser visto. De qualquer modo, não é exclusivamente no espaço público que as relações e os laços se consolidam: é o lugar onde são exibidos, divulgados, mas encontram outros canais para se estabelecerem.

Portanto, mesmo se tratando de uma cidade relativamente pequena, do Interior, (alguém poderia dizer que talvez seja exatamente por isso) o convívio entre diferentes é algo que acontece pouco. Mas isso expressa, também neste contexto, um problema social contemporâneo: a convivialidade - entre gerações distintas, entre raças distintas, entre classes sociais distintas - tem cada vez menos oportunidades para acontecer ${ }^{10}$. Morar em condomínios fechados, em prédios considerados "com segurança" ou em casas com altas grades, são ideais de moradia que predominam na estética local e nos jogos de prestígio social. Considerar que a televisão é prejudicial e excessivamente violenta, especialmente para o "outro", este desconhecido e anônimo a quem se atribui muito, foi um imaginário quase palpável que a pesquisa revelou. N este contexto, o medo da violência encontra terreno fértil para se desenvolver.

10 É o que aponta, por exemplo, O liveira (2003, p. 95 e 99), ao propor repensar as articulações entre vida privada e trabalho. Numa inovadora reflexão sobre a pressão de tempo à qual estão submetidas as famílias de hoje, e sobre o lugar das mulheres e dos homens - na vida privada e na vida pública, no cuidado dos filhos e dos idosos - propõe que a solução não é doméstica, mas do mundo público, dos governos e das empresas, promovendo a reengenharia do tempo. Aumentar o convívio entre gerações, aumentar os laços de socialidade contribuiria para novos aprendizados: aprender a aprender, aprender a ser na nova sociedade informatizada. 
$\mathrm{Na}$ continuidade da pesquisa, trabalhamos junto às delegacias locais, analisando os chamados Boletins de O corrência. Estes, como sabemos, são elaborados sempre que uma pessoa queixosa deseje registrar um fato no qual se tenha sentido lesada e que precise de providências das autoridades policiais. U ma vez que se trata de registros genéricos, os quais poderão dar origem a um processo ou não, dependendo de vários fatores, naquele momento nos serviram mais como estímulo à reflexão do que como medidores. Eles não apresentavam relatos significativos que ajudassem a explicar a percepção de "cidade violenta" expressa pelos moradores.

Nos jornais locais, as notícias da coluna policial eram, em sua maioria, sobre pequenos furtos: roubos de som de carros cuja garagem ficara aberta (e carro idem); de roupas de varal e tênis em pátios de casas; de carteiras em painel de carro aberto na rua, etc. Ainda que sem medidores, podíamos perceber, nos registros das delegacias, jornais e rádios locais, que os crimes violentos e à mão armada eram bem mais raros.

Buscamos também dados em uma pesquisa panorâmica sobre a violência em todo o Estado do Rio Grande do Sul, desenvolvida por uma equipe de estudiosos da UFRGS $S^{11}$, e descobrimos que não havia registros que permitissem considerar a cidade singular; não havia destaques nos índices de violência a respeito daquela região, a noroeste do Estado.

Os vários caminhos de pesquisa - quantitativos e qualitativos, de variadas fontes, mostravam que a percepção social da violência local era maior do que os registros permitiam visualizar: a chamada cultura do medo ou o sentimento de medo estava imperando. Parece que era o conjunto de pequenos furtos dos quais se tinha notícia, reproduzidos não só nos meios de comunicação locais, mas também em relatos assustados entre as pessoas no cotidiano, e que conferia ao lugar toda a fama de cidade peri-

11 Refiro-me à pesquisa realizada por José Vicente Tavares dos Santos, que resultou na publicação "Violência em tempos de globalização", de 1999. 
gosa. Esses relatos eram depois comparados ao que se via nos noticiários nacionais - que expressavam o aumento da criminalidade violenta ou a banalização da morte - e pareciam confirmar que ali também se vivia um cotidiano violento, semelhante ao da abordagem televisiva.

Este contexto pode estar revelando uma preocupação coerente com a dos representantes da chamada Escola de Chicago. Estes buscavam, em seus estudos do início do Século XX, entender o "caos urbano", numa proposta à qual subjazia uma idéia de saneamento, coerente com uma base científica da época, segundo a qual caberia aos cientistas elaborar teorias que pudessem servir de base a intervenções políticas ordenadoras ${ }^{12}$. Mas o referido contexto pode também estar questionando as idéias de isolamento a que está submetida uma cidade do Interior, especialmente num período de acesso a novas tecnologias e a informações mundiais, não só sobre violência. A preocupação das pessoas pesquisadas com a violência e os roubos, apresentados de modo desproporcional em relação à sua gravidade, como característica da cidade onde moram, talvez revele um desejo de definir o lugar como um centro urbano moderno ${ }^{13}$.

Ao lado dessa percepção generalizada de "cidade violenta" no contexto local e dos ideais de moradia expressados (que eram muito semelhantes aos de grandes centros urbanos), havia a suposição de que a mídia, em especial a televisão, cria comportamentos violentos e ensina - especialmente os jovens e principalmente os pobres - a cometerem crimes. Não se pode falar em consenso entre os pesquisadores a respeito dessa relação entre

12 Refiro-me, por exemplo, a Simmel (1979) para quem o caos urbano obriga o indivíduo a se relacionar com recortes dessa realidade; ou a Wirth (1979), que chamava a atenção para a necessidade de definir o significado do "modo de vida urbano", sem associar mecanicamente "urbano" e "cidade".

13 Agradeço a Ana Luiza Carvalho da Rocha por me chamar a atenção para este aspecto, em debate sobre a pesquisa, no Seminário "Antropologia das Sociedades Complexas", do PPGAS/ UFSC, 2000. 
horas em que se assiste TV, ou a relação entre audiência de determinados programas considerados violentos, ou mesmo a prática de videogames, e um suposto comportamento violento dos jovens. Mas pode-se afirmar que não há certezas ou evidências científicas sérias a respeito dessa relação ${ }^{14}$.

U ma das explicações para essa visão que atribui aos meios de comunicação de massa a criação da violência poderia ser aquela que outros estudiosos também têm enfatizado. Culpar a televisão pela violência pode ser um modo de sentir-se fora dela, sentir-se isento de responsabilidades, como afirma Sérgio Adorno (1995) referindo-se à imprensa.

Essa afirmação, junto com a observação da postura das pessoas pesquisadas, convidam-nos a uma reflexão sobre os processos sociais através dos quais se criam os estereótipos, as evitações de convívio, os rótulos sobre quem é o "marginal" ou "bandido". Certamente vamos encontrar várias maneiras e lugares para sua construção e expressão: a família, a vizinhança, a escola, os grupos fechados dos considerados "iguais". E também estarão presentes de um modo ou outro nos meios de comunicação de massa: os jornais, o rádio, a televisão, o cinema, os quadrinhos, poderão expressá-los de várias maneiras - que poderão ir desde o "politicamente correto" até a mais grosseira abordagem. Mas responsabilizar os meios de comunicação pela sua criação é, sem dúvida, uma das formas de se isentar de sua criação e/ou difusão em vários outros jogos da interação social.

N otamos o fascínio que esse tipo de notícias exerce: apesar da crítica enfática que os pesquisados faziam ao excesso de violência nos telejornais, a dramatização da violência na TV parecia atender às suas expectativas enquanto público, pois eles estavam sempre "por dentro" do que tinha sido abordado nos noticiários dos quais reclamavam, provavelmente contribuindo para os altos índices de audiência.

14 Como exemplo, temos o livro Televisão, criança, imaginário e educação, organizado por Elza Dias Pacheco, o qual conta com uma série de artigos que expressam esta polêmica entre televisão e influência sobre as crianças. Ver Pacheco (1998). 
M uitas das pessoas pesquisadas afirmavam que a violência se transmite pela mídia, parecendo supor que a TV cria realidades. Criticar a televisão, tentar sugerir uma programação educativa e, ao mesmo tempo, fornecer altos índices de audiência à programação existente, bem como adquirir aparelhos cada vez mais sofisticados, parecia ser uma constante. Adorno pode ajudar novamente na compreensão deste aspecto: ele chega a referir-se ao fenômeno da dramatização como "expressão da opinião pública". O u seja, o público, fornecendo altos índices de audiência, é que alimentaria de modo indireto a escolha deste que seria um estilo de programa. Para ele, "essa dramatização não é a fabricação de uma inverdade, mas é um gênero, um modo de colocar em discurso uma certa reação diante de problemas, conflitos e questões difíceis de serem socialmente enfrentadas" (ADORNO, 1995, p. 26).

Compreende-se, então, por que algumas das pessoas mais críticas eram justamente as que possuíam telões, além de três ou quatro aparelhos de televisão em casa ${ }^{15}$. Encontramos TVs na sala, no quarto, na cozinha e até no banheiro! E essa prática conferia uma especialização em TV e contribuía para que a crítica à mesma fosse bastante detalhada, considerando-a violenta e prejudicial. A percepção generalizada era de que a violência estava aumentando. A televisão era considerada mais prejudicial às "classes mais baixas", e as pessoas pertencentes a estas classes eram consideradas como pessoas que tinham uma tendência anterior para o crime, sugerida como inata ${ }^{16}$ :

15 Cabe destacar que as pessoas pesquisadas, pelo seu estilo de ver a TV, podem ser consideradas especialistas no assunto: é exatamente a grande experiência, a prática cotidiana de ver televisão, aliada ao conhecimento da existência de técnicas de edição (seja através dos próprios programas televisivos que mostram o making off de filmagens, seja através da participação em entrevistas depois editadas) que afina sua crítica sofisticada a toda programação. Esta especialização demonstra que a prática de ver televisão é muito maior do que se admite. Ver a respeito, Magalhães (2004). Devo a Sônia M aluf a sugestão de considerá-los especialistas.

16 As pessoas entrevistadas eram profissionais liberais, bancários, funcionários públicos, professoras, donas de casa. Seus nomes foram omitidos para preservar o anonimato. 
"As reportagens estimulam e influenciam para o negativo, ensinando truques de assaltos, roubos para as pessoas que têm tendência para isso, os de classe mais baixa, embora alta também, mas de forma diferente" (A).

"As reportagens acabam informando os assaltantes, as quadrilhas, sobre o que a polícia está fazendo" (B).

“A TV é apelativa, exagerada. 0 que nos interessa saber se alguém que desconhecemos traiu, matou? Fico admirado quando vejo que as pessoas se interessam por isso" (D)

“Está ocorrendo um acréscimo de violência de um modo geral, mas as cenas diárias de crimes cometidos por jovens podem concorrer para que outros jovens os pratiquem...". (G)

O s telejornais são reconhecidos como possuindo um gênero narrativo predominante, a dramatização da violência, que confirma a percepção generalizada de seu aumento:

“Eu acho que todos os jornais... tem um do SBT, que só pega violência, polícia. Este da Globo que agora está dando alguma coisa que dá para aproveitar mais tarde. Senão, o dia-a-dia é assim: violência, derrubam postes, pegas..." (C).

"Assisto o Jornal N acional, mas não gosto quando eles enfatizam muito os crimes" (E).

“O Jornal Nacional é um dos jornais da televisão que a gente vê mesmo, praticamente todos os dias. Apesar de, às vezes... ultimamente ele está de competição com outros telejornais. É tipo 'A vida como ela é', mostrando a realidade da violência, da violência urbana, nas famílias, na favela". (F)

"Mas pode notar: não tem uma notícia boa, não tem uma notícia que incentive nada" (A).

U m tema recorrente à época da pesquisa nos telejornais era uma notícia sobre o então denominado "maníaco do parque", um criminoso que atraía e atacava mulheres em um parque, em São Paulo, fato ampla- 
mente noticiado pelos meios de comunicação. U ma das mulheres pesquisadas referiu-se indiretamente ao assunto:

“Caminhar sozinha à noite é muito perigoso. U ma vez eu saí para caminhar à tardinha e um homem me seguiu. Ele dizia umas coisas, fiquei tão nervosa que nem me lembro o quê. Ele podia ser um maníaco". (H)

Esse temor das mulheres de serem atacadas não é específico de nosso período histórico, é uma recorrência numa sociedade em que a dominação masculina pela força ficava impune (situação que vem mudando lentamente). As notícias veiculadas pela televisão sobre o caso, provavelmente fizeram aumentar um temor já existente e também forneceram um novo repertório lingüístico para um fenômeno já conhecido. O utra nominação antiga poderia já haver para o homem que persegue e ataca mulheres, mas essa nominação foi substituída rapidamente pela usada nos meios de comunicação - "maníaco" - ainda que o significado fosse o mesmo. No meu entender, essa "comunidade de sentido" em torno da nova nominação só é possível de ser propagada tão rapidamente porque ela é amalgamada por uma grande experiência anterior. Ela só "faz sentido" agora porque já fazia sentido antes, na vivência das pessoas. Parece-me uma prova de que a televisão ou os meios não criam valores e significados a partir do zero.

Mas quem fica procurando a "série" no crime são os repórteres: a partir de então, todos querem descobrir um "assassino serial" nas suas cidades, pois isso terá lugar garantido na pauta do jornal. Isto confirma 0 que diz Bourdieu (1997): na busca do furo, cria-se a homogeneidade da mensagem. Mas é na produção da mensagem, na sua emissão, que se cria esta homogeneidade, note-se bem. Isto não significa que a mesma mensagem será recebida passiva e homogeneamente.

Refletindo sobre os dados da pesquisa e sobre as abordagens teóricas a respeito da espetacularização da violência, encontrei-me ante algumas assertivas que se mostraram enganosas: reconhecer que existe um sentimento de medo da violência, exacerbado pelo espetáculo televisivo, na- 
quele contexto de interior (lido como pacato por quem é de fora), podia levar-me a acreditar que a violência ali não existia como em outros lugares e que a ficção televisiva é que criava a forte sensação de sua gravidade. M as este raciocínio continha uma dupla armadilha: uma, negar a importância do aumento e impacto da violência na sociedade de hoje $\mathrm{e}^{17}$; outra, acreditar que a televisão é que cria a realidade da violência.

Como entender, então, as suposições das pessoas pesquisadas, sem reificar a capacidade televisiva de criação? Eu poderia considerá-las simplesmente como parte de uma explicação "espontânea" do "senso comum" e ir em busca de explicações "mais sérias" sobre o tema. M as parece-me fundamental debater esta visão, pois é preciso considerar as conseqüências sociais e políticas que geram estes posicionamentos (além de ser ela compartilhada por muitos acadêmicose especialistas, como sabemos ${ }^{18}$ ). São posicionamentos que inspiram um debate permeado por uma série de estereótipos, como a desqualificação do popular, a evitação do diferente, a construção de um "perfil de periculosidade", suposto muitas vezes como criado pelo universo televisivo, e do qual nos isentamos ${ }^{19}$. E isto aparece no campo de análise da interpretação das mensagens, e não apenas na produção das mesmas, ou seja, está presente no processo de comunicação mais amplo e na vida em sociedade.

17 Como demonstram, por exemplo, as pesquisas desenvolvidas por Lourdes Bandeira (1999). 18 Muitas vezes, os episódios abordados exaustivamente pela televisão geram pressões sobre os órgãos públicos, os quais se vêem compelidos a tomar medidas. N estes momentos, retornam ao debate propostas de rever a maioridade penal ou a instituição da penalidade de morte no Brasil. O s profissionais que trabalham com justiça restaurativa podem ajudar, com reflexões e proposições de ação, a resolver de outro modo os conflitos. Agradeço aos pesquisadores do $\mathrm{NACl}$ - Núcleo de Antropologia e Cidadania - do PPGAS/UFRGS, por me colocarem em contato com essa perspectiva de ação e análise.

190 debate sobre a "falta de cultura" no Brasil, que seria característica de uma população "atrasada" e pobre, impedindo-a de entender as tentativas da televisão de enganá-la, combina com a explicação que atribui a responsabilidade pelo "atraso brasileiro" a esta mesma população e não à elite, por exemplo. Ver Magalhães (2006). 
O debate aqui proposto está mostrando que não basta reafirmar que as mensagens televisivas são estereotipadas (como de fato são, na maior parte das vezes); sabemos também que, na ótica das ciências sociais, tampouco podemos considerar que a TV crie valores (pois sabemos que os valores se criam no processo social, inclusive a importância atribuída à TV). Também não basta reafirmar que os receptores reelaboram as mensagense criam novos significados para elas, distanciando-se da intenção dos produtores, num sentido idílico (pois essa reinterpretação, exatamente por ser múltipla, pode ser num sentido negativo e estereotipado). Mas talvez sirva para reafirmar a importância política de debater o ângulo de abordagem adotado pela televisão e por seus intérpretes diários, pois ambos os campos - dos criadores das mensagens e de seus intérpretes - contribuem para gerar novos significados para vários problemas sociais, entre eles as violências.

\section{Espetáculo, realidade virtual, imagem... E as interpretações?}

O s debates atuais em torno da noção de "realidade virtual" têm-se revelado um campo que eu chamaria de "pós-apocalíptico". Refiro-me a um debate proposto por Umberto Eco, entre dois campos teóricos que debatiam a influência dos meios de comunicação na sociedade: os apocalípticos e os integrados. É muito conhecida e hoje considerada clássica nos estudos de comunicação esta "divisão": de um lado, os apocalípticos, que consideram, "como Heráclito20, a cultura como um fato aristocrático", perante o qual a cultura de massa torna-se o sinal de uma queda irrecuperável e o "homem de cultura, o profetizador de seu desaparecimento perante o apocalipse da massificação" (ECO, 1979, p. 8); de

20 Eco faz uma citação de Heráclito: "Por que quereis levar-me a toda parte, ó iletrados? Não escrevi para vós, mas para quem me pode compreender. Um, para mim, vale cem mil, e a multidão, nada" (ECO, 1993:8) 
outro lado, os integradosque, tal como seus oponentes, assumem o conceito-fetiche de massa, pretendem construir seus projetos para ela, educar a massa, operando um reducionismo no seu interior: há uma ausência de sujeitos na massa (Id, p. 18).

Poderíamos, talvez, considerar que os analistas da realidade virtual estão num campo pós-apocalíptico? A julgar pelo tom de "queda irrecuperável" do social, pelo vazio que julgam criar-se numa sociedade da imagem e da imediaticidade da experiência, podemos supor que sim. Q uando falamos em realidade virtual, podemos estar falando em mais uma representação construída sobre o real, no coletivo, construção que tem por referência as novas práticas, novas sociabilidades construídas num período de criação e acesso a novas tecnologias. M as, para Virílio (1993), por exemplo, a perspectiva é bastante pessimista, pois, como afirma Parente (1997, p. 141), para ele "as tecnologias do virtual se impõem como estética da desaparição que substitui o real; estética do hiper-real que despotencializa o real; buraco negro que aniquila o referente".

A análise dessas novas possibilidades de construção de sociabilidades tem merecido enfoques predominantemente negativos. Muitos estudiosos, trabalhando numa perspectiva crítica à sociedade contemporânea, ao processo de "coisificação" do sujeito diante de uma sociedade na qual a imagem é cada vez mais central, acabam repondo essa coisificação sobre este mesmo sujeito. Entre eles, por exemplo, Jeudy, quando afirma que hoje não se pode mais falar que a "mídia" é o espelho da realidade:

se opusermos realidade externa à mídia, no final essa realidade externa será captada por ela e se transformará em imagem! Então, não há possibilidade - e esse é o problema - de operar uma distinção entre a imagem e o real. O ra, o processo mediático, no seu conjunto, na sua vertigem...não funciona mais como um espelho da sociedade. Hoje, não podemos mais dizer que a mídia tem uma função especular em rela- 
ção à sociedade, que ela 'revela' a imagem da sociedade". (JEUDY, 1994, p.68; grifo meu).

Para o autor, a "mídia" alucina o real no momento em que desaparece a distinção entre imagem e realidade. No meu entender, algumas de suas afirmações podem ser problematizadas, entre elas a concepção de realidade e a agência na construção e interpretação de imagens. Ele parece estar trabalhando com uma concepção que opõe realidade concreta e realidade inventada: se a realidade externa se transformará em imagem construída pela mídia, então parece que ele está supondo que a agência será só da "mídia"; ele não está considerando o leitor dessa imagem. A imagem construída sobre a realidade substituirá esta realidade, e como isto será feito pela "mídia" (supõe-se, pelo viés adotado, que ele considera essa construção totalmente ilegítima), indiretamente ele está afirmando que existe um novo processo social em curso (de transformação do real em imagem), que é resultado da criação da mídia, à parte da sociedade.

Aqui cabe o resgate da discussão sobre a construção e leitura de imagens numa outra lógica, diferente da coisificação ocidental e mais próxima da especulação imaginativa, como propõem algunsestudiosos. ${ }^{21}$ Também a imagem, como o texto, é produto de certo "recorte", mas parece que não lhe é atribuída legitimidade para "recortar" a realidade (nem à imagem, nem aos criadores de imagem). Nas abordagens em que se diz que a imagem substitui o real, estará sendo exigido da imagem em movimento aquilo que era exigido da fotografia no seu surgimento, que comprovasse o real? Será que está sendo criticada a imagem como algo negativo em si, ou certas imagens construídas de modo considerado ilegítimo? Esta diferenciação muitas vezes não fica clara e contribui para que a coisificação da imagem seja ampliada de modo assus-

21 Cf. discussão feita por Carvalho da Rocha (1995, p. 89), e também abordada em Magalhães (2004). 
tador, pois não há "sujeitos" (nem na construção, nem na interpretação) num tipo de abordagem do real e da imagem como esta.

A discussão sobre o que é a realidade, se podemos (ou devemos) nos aproximar dela ou não, se esta é a tarefa por excelência do conhecimento científico, ou se é irrealizável, tem marcado as ciências sociais. Sobretudo na década de 1980, o debate ocupou o centro das indagações sobre a cientificidade ${ }^{22}$. Rabinow (1986) e também Foucault (1999) responderam este questionamento de forma semelhante: propuseram reconhecer que existe uma realidade, da qual o saber científico só pode tentar aproximações, sem nunca ter a pretensão de tê-la esgotado. Propuseram, portanto, reconhecer que o saber científico não coincide com a realidade, é uma construção sobre ela, e isso não significa que seja falso ${ }^{23}$.

Talvez um dos caminhos para formularmos novas perguntas (tarefa por excelência do conhecimento científico não dogmático) seria considerar que, no processo social em curso, emerge uma nova maneira de se relacionar com o real, com a mediação da imagem ou com outros significados atribuíd os à imagem, que podem ser positivos ou negativos, depende dos usos e interpretações que se faça ${ }^{24}$. O utra possibilidade é, ao supormos que a diluição entre imagem e real esteja acontecendo, considerar que este seria um processo social mais amplo, ao qual estaríamos todos sujeitos, inclusive os produtores da "mídia" e seus leitores-receptores. E assim poderiam multiplicar-se as análises e talvez fôssemos encontrar também muitos outros questionamentos e pistas para futuras pesquisas.

22 Ver, a respeito, Tavares do Santos (1993)

23 Ver, por exemplo, discussão proposta por Rabinow em "Representations are socail facts: modernity and post-modernity in Anthropology", in Clifford e Marcus (1986) e entrevista de Foucault ao mesmo Rabinow em 1983, publicada no Brasil em 1999.

24 Cf. as tendências que têm marcado os debates realizados no GT de Antropologia Visual da RAM (Reunião de Antropologia do Mercosul), como foi o caso das realizadas em Curitiba, 2001, e Montevidéu, 2005. 
Considerar que a "mídia" cria uma realidade virtual, sem a participação da sociedade, como se ela fosse um ente à parte do social, com vida própria (mas sem sujeitos) e como se essa realidade virtual, por outro lado, fosse uma não-realidade, constituem, no meu entender, um processo de reificação, da "mídia" e da realidade. Mas as pesquisas não precisam tomar este rumo nem permanecer nestes pressupostos.

A televisão trabalha com uma visão no singular - em oposição a plural - sobre violência, apresentando-a como drama e como espetáculo25. Este espetáculo tem seu ápice na tragédia, é exacerbado nos vários "excessos", apresentados como o perigo extremo ao qual estamos todos sujeitos. A visão negativa sobre a violência é construída de modo tal, como se houvesse um paraíso anterior, que foi perdido e, na nossa época, vivêssemos um mar de violência, nunca antes conhecido (RIFIOTIS, 1999). Mas isso seria o que faz a TV ou o emissor. E o receptor? Q uando nos alarmamos com a violência na TV, estamos desconsiderando-o.

A mídia tem tratado a violência predominantemente como espetáculo, tem exacerbado a dramatização e, com isso, tem contribuído para reforçar uma visão no singular sobre a violência, que é a sua exclusiva negatividade. Contraditoriamente, ao alarmar-se e ressaltar somente 0 aspecto negativo, distancia-se da violência no plural, no cotidiano, fazendo parte das relações sociais. Na guerra pela audiência a qualquer preço, acaba criando uma narrativa descolada da sociedade, constrói um texto ficcional que poderíamos considerar como parte do campo da estética: tintas exageradas, tragédia exacerbada.

Q uando os cientistas sociais não tratam a violência como espetáculo, não a consideram de modo simplista em crescimento e tentam 
entender seus múltiplos significados, estão numa direção oposta do que a mídia tem feito com o tema. Podemos supor que, deste modo, não estão contribuindo nem para a dramatização nem para exacerbar a percepção de aumento da violência e o sentimento de insegurança daí decorrente. $M$ as quando a consideram (como as pessoas pesquisadas) com uma capacidade criadora do real - mesmo que, para isso, sofisticando o debate teórico e denunciando o vazio da sociedade da imagem ou da realidade virtual - entram num caminho de retroalimentação de um sentimento de perigo que pouco contribui, seja no combate à violência, seja na evitação da criação de estereótipos.

No caso do grupo estudado, o tema da violência apareceu como interesse dos entrevistados, e eles manifestam a crença de que a TV tem a capacidade de moldar comportamentos e pensamentos, além de estarem mergulhados numa percepção de aumento da violência e de um sentimento de insegurança muito grande. Este, causado não só pelo que é sentido e imaginado através das imagens espetaculares da mídia, mas pela vida cotidiana numa cidade que é considerada violenta pela maioria de seus moradores.

Cabe também aos estudiosos das violências e seus múltiplos significados, construir uma reflexão acerca de sua crítica à mídia: estarão supondo que a mídia tem o poder de criar valores e ela seria a grande responsável pela construção de um único significado, negativo e singular, para a violência? Como tentamos demonstrar, o caminho de construção dessa negatividade não é um caminho de mão única: é no processo social que ele se constrói.

\section{The meanings of violence in the television message}

\section{Abstract}

This article discusses the multiple meanings of violence identified by researchers, comparing them to empirical studies conducted in a mid-size city in 
Rio Grande do Sul, Brazil. Subsequently, it considers the absence of these various meanings, both in the television show and in the perception of the people surveyed, as well as the presence of stereotypes in the construction of the television messages and its interpretations. Furthermore, the article intends to present more data to explain the perception of the interviewed people on the increase in violence within the local context. To conclude, the author questions the culture of fear, suggesting that it can be powered not only by the apprehension of the people surveyed who watch the TV show, but also by the way some researchers analyze the same show. The discussion aims to show that there are reified conceptions of violence, image and reality, within the debate, that give power to the perception of an increase in violence and the resulting sense of insecurity.

Keywords: Violence. Reception studies. Television show. Culture of fear. Media anthropology.

\section{Referências}

AD O RNO, Sérgio. Violência, ficção e realidade. In: SO USA, Mauro Wilton (org.). Sujeito, o lado oculto do receptor. São Paulo: Brasiliense, 1995.

BAND EIRA, Lourdes e SUÁREZ, Mireya (orgs.). Violência, gênero e crime no Distrito Federal. Brasília: Paralelo 15/Editora da U niversidade de Braślia, 1999.

BO U RDIEU, Pierre. Sobre a Televisão. Rio de Janeiro: Jorge Zahar Editor, 1997.

ECO, U mberto. Apocalípticos e Integrados. São Paulo: Perspectiva, 1993 (5ª edição).

ECO, U mberto. Pour une guérilla semiologique. In: La Guerre du faux. Paris, Livre du Poche, 1988.

FOU CAU LT, Michel. Política da Verdade. Paul Rabinow entrevista Michel Foucault. In: RABIN O W, P. Antropologia da Razão. Rio de Janeiro: Relume Dumará, p. 17-25, 1999.

GID DENS, Anthony. A Transformação da Intimidade: sexualidade, amor e erotismo nas sociedades modernas. São Paulo: Ed. U NESP, 1993.

GIRARD, René . A violência e o sagrado. São Paulo: Paz e Terra/Ed. UN ESP, 1990. KATZ, Jack. W hat makes crime 'news'? In: ERICSO N, Richard (ed.). Crime and the Media. Brookfield: Darthmouth Publishing Company, 1995. 
MAFESO LI, Michel. La violence ou le desir du collectif. In: MAFESO LI, Michel ; BRU STO N, André (org.) Violence et transgression. Paris: Anthropos, 1979.

MAGALHÃES, Nara. Televisão, uma vilã na sociedade contemporânea: um estudo sobre os modos de ver (a) TV de pessoas pertencentes a camadas médias. Tese de Doutorado, PPGAS/UFSC, abril de 2004.

. Reflexões sobre a televisão e a "falta de cultura" no Brasil. Revista Em Questão, Porto Alegre, v.12, n.1, p. 109-129, jan. - jun. 2006.

O SÓ RIO, Luiz Carlos. Agressividade e violência: o normal e o patológico. In: TAVARES D O SSANTO S, José Vicente (O rg.). Violências em tempo de globalização. São Paulo: Hucitec, 1999, p. 522-543.

PARENTE, André. Cibercidades. In: Revista Lugar Comum: Estudos de Mídia, Cultura e Democracia, no. 2-3, julho-novembro 1997, pág. 132 - 145.

RABIN OW, Paul. Representations are social facts: modernity and post-modernity in Anthropology, in Clifford e Marcus, Writting Culture. Berkeley: U niversity of Califórnia Press, 1986.

RIFIOTIS, T. Nos campos da violência: diferença e positividade. Antropologia em Primeira Mão, no. 19, 1997, pág. 1 - 18.

. A Mídia, o leitor-modelo e a denúncia da violência policial: o caso Favela Naval. In: Revista São Paulo em Perspectiva, no. 13 (4), pág. 28-41, 1999.

RO CHA, Rosamaria L. M. Estética da violência: por uma arqueologia dos vestígios. Tese de Doutorado. Escola de Comunicação e Artes - ECA/U SP, São Paulo, 1997.

SIM M EL, George. The Conflict in Modern Culture and 0 ther Essays. New York: Teachers College Press, 1992.

. A metrópole e a vida mental. In 0 Fenômeno Urbano. VELHO, O. (org.). Rio de Janeiro: Zahar Editor, 1979.

SO ARES, Luiz Eduardo et alli. Violência e Política no Rio de Janeiro. Rio de Janeiro: ISER/Relume Dumará, 1996.

TAVARES DOS SANTOS, José Vicente. Violência em Tempos de Globalização. São Paulo: Hucitec, 1999.

. A Aventura Sociológica na Contemporaneidade. In: AD O RNO, Sergio (org.) A Sociologia entre a modernidade e a contemporaneidade. Cadernos de Sociologia. Porto Alegre: PPGS/U FRGS,1993.

TEIXEIRA, Alex Niche. A Espetacularização do Crime Violento pela televisão: 0 caso do Programa Linha Direta. Dissertação de Mestrado. Programa de Pós-Graduação em Sociologia, UFRGS, outubro de 2002. 
VIRILIO, Paul. 0 espaço crítico. Rio de Janeiro: ED 34, 1993.

W EBER, Max. Ciência e política, duas vocações. São Paulo: Cultrix, 1967. . Economie et societé. Paris: Plon. 1971.

WIRTH, L. O urbanismo como modo de vida. In: VELHO, O távio (org.). 0 Fenômeno urbano. Rio de Janeiro: Zahar Editor, 1979.

ZALUAR, Alba. A Máquina e a Revolta. São Paulo: Brasiliense, 1985.

A globalização do crime e os limites da explicação local. In: TAVARES DOS S̄ĀNTOS, José Vicente. Violência em Tempo de Globalização. São Paulo: Hucitec, 1999.

Recebido: 29/11/2007

Aceite final: 20/12/2007 